\title{
Combined presence of four individually weak genetic variants strongly increases cancer risk
}

\author{
Hermann M. Bolt ${ }^{1}$
}

Received: 9 November 2017 / Accepted: 13 November 2017 / Published online: 15 November 2017

○) Springer-Verlag GmbH Germany, part of Springer Nature 2017

Recently, large efforts have been invested into genome-wide association studies to identify genetic variants that confer urinary bladder cancer risk (Rothman et al. 2010; Selinski 2014C; Rafnar et al. 2014, 2011, 2009; Kiemeney et al. 2008, 2010; Garcia-Closas et al. 2011; Figueroa et al. 2016, 2014). Usually, the odds ratios of individual variants are low and do not exceed 1.4 (Selinski 2012, 2014a, b; Golka et al. 2011; Schwender et al. 2012). Recently, Selinski et al. (2017) have performed a large study including most of the currently known high-risk genetic variants of urinary bladder cancer. All individual variant odds ratios were only between 1.11 and 1.30 (Selinski et al. 2017). However, the authors discovered a four-variant combination that confers an odds ratio of 2.59 (95\% confidence interval of 1.93-3.47). Importantly, this combination of four risk variants is relatively frequent, with approximately $25 \%$ in bladder cancer cases and $11 \%$ in controls of a European population (Selinski et al. 2017). The interaction of risk variants was stronger in never smoking individuals than in smokers. This example demonstrates that relatively weak individual genetic variants, also named 'wimp SNPs' (Golka et al. 2011), can statistically interact to confer a much higher risk in combination.

Urinary bladder cancer is known to be caused by a combination of environmental factors, such as aromatic amines and genetic predisposition (Höhne et al. 2017; Krech et al. 2017; Lukas et al. 2017; Selinski et al. 2015). The majority of currently published studies on genetic polymorphisms still focusses on individual SNPs (Pellé et al. 2016; Huang et al. 2016; Geller et al. 2016; Fujihara et al. 2016; Chu et al. 2016; Liaqat et al. 2015; Hashemi et al. 2015; Anvar et al. 2011). However, the present study of Selinski et al. (2017) demonstrates that it is particularly important to identify

Hermann M. Bolt

bolt@ifado.de

1 IfADo, Leibniz Research Centre for Working Environment and Human Factors at TU Dortmund, Ardeystr. 67, 44139 Dortmund, Germany combinations of SNPs that together have a much stronger impact than the sum of individual variants. However, this approach is challenging, because extremely high numbers of cases and controls are needed. The present study (Selinski et al. 2017) included 5049 bladder cancer cases and a similar number of controls to identify statistical interactions of four genetic variants. However, it can be expected that even higher numbers of SNPs interact, which in future confronts scientists with the challenge to organize much larger cohorts of cases and controls.

\section{References}

Anvar Z, Saadat I, Namavar-Jahromi B, Saadat M (2011) Genetic polymorphisms of glutathione $S$-transferase M1 (GSTM1) and T1 (GSTT1) and susceptibility to pre-eclampsia: a case-control study and a meta-analysis. EXCLI J 10:44-51

Chu H, Zhong D, Tang J, Li J, Xue Y, Tong N, Qin C, Yin C, Zhang Z, Wang M (2016) A functional variant in miR-143 promoter contributes to prostate cancer risk. Arch Toxicol 90(2):403-414

Figueroa JD, Ye Y, Siddiq A et al (2014) Genome-wide association study identifies multiple loci associated with bladder cancer risk. Hum Mol Genet 23(5):1387-1398. https://doi.org/10.1093/hmg/ ddt519

Figueroa JD, Middlebrooks CD, Banday AR et al (2016) Identification of a novel susceptibility locus at 13q34 and refinement of the 20p12.2 region as a multi-signal locus associated with bladder cancer risk in individuals of European ancestry. Hum Mol Genet 25(6):1203-1214. https://doi.org/10.1093/hmg/ddv492

Fujihara J, Yasuda T, Iwata H, Tanabe S, Takeshita H (2016) Association of XRCC1 polymorphisms with arsenic methylation. Arch Toxicol 90(4):1009-1012

Garcia-Closas M, Ye Y, Rothman N et al (2011) A genome-wide association study of bladder cancer identifies a new susceptibility locus within SLC14A1, a urea transporter gene on chromosome 18q12.3. Hum Mol Genet 20(21):4282-4289. https://doi. org/10.1093/hmg/ddr342

Geller F, Soborg B, Koch A, Michelsen SW, Bjorn-Mortensen K, Carstensen L, Birch E, Nordholm AC, Johansen MM, Børresen ML, Feenstra B, Melbye M (2016) Determination of NAT2 acetylation status in the Greenlandic population. Arch Toxicol 90(4):883-889

Golka K, Selinski S, Lehmann ML, Blaszkewicz M, Marchan R, Ickstadt K, Schwender H, Bolt HM, Hengstler JG (2011) Genetic 
variants in urinary bladder cancer: collective power of the "wimp SNPs". Arch Toxicol 85(6):539-554. https://doi.org/10.1007/ s00204-011-0676-3. Review

Hashemi M, Sharifi-Mood B, Rasouli A, Amininia S, Naderi M, Taheri M (2015) Macrophage migration inhibitory factor $-173 \mathrm{G} / \mathrm{C}$ polymorphism is associated with an increased risk of pulmonary tuberculosis in Zahedan, Southeast Iran. EXCLI J 14:117-122

Höhne S, Gerullis H, Blaszkewicz M, Selinski S, Hengstler JG, Otto T, Golka K (2017) $N$-acetyltransferase $1 * 10$ genotype in bladder cancer patients. J Toxicol Environ Health A 80(7-8):417-422

Huang CY, Pu YS, Shiue HS, Chen WJ, Lin YC, Hsueh YM (2016) Polymorphisms of human 8-oxoguanine DNA glycosylase 1 and 8-hydroxydeoxyguanosine increase susceptibility to arsenic methylation capacity-related urothelial carcinoma. Arch Toxicol 90(8):1917-1927

Kiemeney LA, Thorlacius S, Sulem P et al (2008) Sequence variant on 8 q24 confers susceptibility to urinary bladder cancer. Nat Genet 40(11):1307-1312. https://doi.org/10.1038/ng.229

Kiemeney LA, Sulem P, Besenbacher S et al (2010) A sequence variant at $4 \mathrm{p} 16.3$ confers susceptibility to urinary bladder cancer. Nat Genet 42(5):415-419. https://doi.org/10.1038/ng.558

Krech E, Selinski S, Blaszkewicz M, Bürger H, Kadhum T, Hengstler JG, Truss MC, Golka K (2017) Urinary bladder cancer risk factors in an area of former coal, iron, and steel industries in Germany. J Toxicol Environ Health A 80(7-8):430-438

Liaqat S, Hasnain S, Muzammil S, Hayat S (2015) Polymorphism analysis in estrogen receptors alpha and beta genes and their association with infertile population in Pakistan. EXCLI J 14:1085-1094

Lukas C, Selinski S, Prager HM, Blaszkewicz M, Hengstler JG, Golka K (2017) Occupational bladder cancer: polymorphisms of xenobiotic metabolizing enzymes, exposures, and prognosis. J Toxicol Environ Health A 80(7-8):439-452

Pellé L, Cipollini M, Tremmel R et al (2016) Association between CYP2E1 polymorphisms and risk of differentiated thyroid carcinoma. Arch Toxicol 90(12):3099-3109

Rafnar T, Sulem P, Stacey SN et al (2009) Sequence variants at the TERT-CLPTM1L locus associate with many cancer types. Nat
Genet 41(2):221-227. https://doi.org/10.1038/ng.296 (Epub 18 Jan 2009)

Rafnar T, Vermeulen SH, Sulem P et al (2011) European genome-wide association study identifies SLC14A1 as a new urinary bladder cancer susceptibility gene. Hum Mol Genet 20(21):4268-4281. https://doi.org/10.1093/hmg/ddr303

Rafnar T, Sulem P, Thorleifsson G et al (2014) Genome-wide association study yields variants at $20 \mathrm{p} 12.2$ that associate with urinary bladder cancer. Hum Mol Genet 23(20):5545-5557. https://doi. org $/ 10.1093 / \mathrm{hmg} / \mathrm{ddu} 264$

Rothman N, Garcia-Closas M, Chatterjee N et al. (2010) A multi-stage genome-wide association study of bladder cancer identifies multiple susceptibility loci. Nat Genet 42(11):978-984. https://doi. org/10.1038/ng.687

Schwender H, Selinski S, Blaszkewicz M, Marchan R, Ickstadt K, Golka K, Hengstler JG (2012) Distinct SNP combinations confer susceptibility to urinary bladder cancer in smokers and non-smokers. PLoS One 7(12):e51880. https://doi.org/10.1371/journal. pone.0051880 (Erratum in: PLoS One. 2015;10(9):e0137937)

Selinski S (2012) Genetic variants confer susceptibility to urinary bladder cancer: an updated list of confirmed polymorphisms. EXCLI J 11:743-747

Selinski S (2014a) Urinary bladder cancer risk variants: recent findings and new challenges of GWAS and confirmatory studies. Arch Toxicol 88(7):1469-1475. https://doi.org/10.1007/s00204-0141297-4 (No abstract available)

Selinski S (2014b) Impact of urinary bladder cancer risk variants on prognosis and survival. EXCLI J 13:1254-1258

Selinski S (2014c) The post GWAS era: strategies to identify genegene and gene-environment interactions in urinary bladder cancer. EXCLI J 13:1198-1203

Selinski S, Blaszkewicz M, Getzmann S, Golka K (2015) N-Acetyltransferase 2: ultra-slow acetylators enter the stage. Arch Toxicol 89(12):2445-2447

Selinski S, Blaszkewicz M, Ickstadt K et al (2017) Identification and replication of the interplay of four genetic high risk variants for urinary bladder cancer. Carcinogenesis. https://doi.org/10.1093/ carcin/bgx 102 (Epub ahead of print) 